\title{
PENERAPAN AKUNTANSI PERTANGGUNG JAWABAN \\ BIAYA TERHADAP EFISIENSI BIAYA PADA PT. PANCA USAHA PALOPO PLYWOOD
}

\author{
HASBIAH, M. RISAL, SALJU SANUDDIN
}

\begin{abstract}
ABSTRAK
Akuntansi Pertanggungjawaban adalah adalah system yang menerapkan pengumpulan biaya dan penghasilan dari tiap pusat pertanggungjawaban yang ada dalam suatu perusahaan, agar dapat ditelusuri penyimpangan yang terjadi dari anggaran yang telah ditentukan sebelumnya. Variabel dalam penelitian ini terdiri atas dua yaitu : 1) Akuntansi pertanggung jawaban biaya (X) serta 2)Efisiensi Biaya (Y). Penelitian ini bertujuan untuk mengetahui dan menganalisis tingkat efisiensi biaya pada PT. Panca Usaha Palopo Plywood.

Metode Penelitian yang digunakan yaitu Metode Penelitian pustaka dan penelitian lapangan

Berdasarkan hasil penelitian diketahui hasil analisis selisih dapat diketahui tingkat efisiensi biaya yang digunakan dalam proses produksi yang hasilnya menunjukkan tidak ada perbedaan yang signifikan antara selisih (varians) biaya produksi plywood tahun 2008, 2009, 2010 Berdasarkan perhitungan selisih harga bahan baku didapat bahwa pada tahun 2008 dan 2009 terdapat selisih laba sedangkan tahun 2009 terdapat selisih rugi, berdasarkan kuantitas bahan baku tahun 2008, 2009, 2010 tidak terdapat selisih laba maupun rugi, berdasarkan selisih tarif dan selisih efisiensi upah langsung tidak terjadi selisih dan berdasarkan selisih terkendali dan selisih volume maka terjadi selisih laba yang bersifat menguntungkan.

Kesimpulannya bahwa faktor yang dapat meningkatkan efisiensi biaya adalah adanya akuntansi pertanggungjawaban dalam mengawasi kinerja manajer termasuk penetapan biaya standar dan informasi realisasi biaya serta adanya struktur organisasi. Berdasarkan analisis selisih (varians) dapat diketahui tingkat efisiensi total biaya produksi serta perbedaan yang terjadi tidak signifikan antara selisih biaya produksi.
\end{abstract}

Kata Kunci: Penerapan, Akuntansi Pertanggung Jawaban biaya, Efisiensi Biaya. 


\section{Pendahuluan}

\section{Latar Belakang}

Setiap organisasi bisnis mempunyai bagian dan setiap bagian merupakan pusat aktivitas dan setiap aktivitas memerlukan biaya. Biaya yang dikeluarkan pada pusat aktivitas, maka pusat aktivitasnya dinamakan pusat biaya. Pusat biaya biasanya diminta untuk membuat rencana organisasi sesuai dengan lingkungannya. Didalam membuat rencana organisasi secara keseluruhan dan pusat pertanggungjawaban individu di dalam organisasi, diperlukan suatu tehnik yang sangat penting, yaitu penganggaran (budgeting). Anggaran merupakan rencana dalam bentuk angka, biasanya tahunan dan dinyatakan dalam satuan uang. Di dalam mengawasi kinerja, bagian yang paling penting dalam proses tersebut adalah mengukur bagaimana kinerja yang sebenarnya dibandingkan dengan yang direncanakan atau dianggarkan.

Anggaran biaya harus disusun sesuai dengan tingkat manajemen dalam organisasi. Tiap-tiap manajer harus mengajukan anggaran biaya yang berada dibawah tanggungjawab masing-masing. Dengan demikian, jika terjadi sesuatu yang tidak sesuai dengan yang direncanakan dalam anggaran, akan mudah ditunjuk siapa yang bertanggungjawab sebagaimana yang diterapkan oleh PT. Panca Usaha palopo Plywood terhadap efisiensi biaya.

Bagian Keuangan dan Bagian Akuntansi menyusun seberapa besar anggaran dan realisasi biaya yang dikeluarkan dan yang telah merupakan pendapatan agar dapat mencapai target yang diinginkan perusahaan. Dalam pelaksanaan akuntansi pertanggungjawaban yang dilakukan oleh perusahaan yang menunjukkan bahwa pelaksanaan akuntansi pertanggungjawaban masih sering terjadi perbedaan sehingga selisih masih terjadi baik itu didalam pengelolaan yang berupa biaya bahan baku, biaya tenaga kerja, biaya overhead pabrik tidak sesuai dengan yang dianggarkan sehingga akuntansi pertanggungjawaban yang dilakukan oleh perusahaan sangat berperan dalam mengetahui tingkat efisiensi biaya.

Akuntansi pertanggungjawaban sebagai system informasi dalam suatu perusahaan khusus PT. Panca Usaha Palopo Plwood hal ini berkaitan dengan pelaksanaan system perencanaan yang dianggarkan dengan realisasinya dalam perusahaan. Oleh karena itu untuk meningkatkan kinerja maka perusahaan berkeinginan melakukan evalusai terhadap system akuntansi pertanggungjawaban biaya hal ini dimaksudkan agar dapat membantu manajemen dalam menunjang efisiensi biaya serta untuk mengetahui pihak-pihak mana saja yang bertanggungjawab terhadap efisiensi biaya perusahaan.

Masalah penelitian ini adalah bagaimana peranan akuntansi pertanggungjawaban Biaya dalam meningkatkan efisiensi biaya pada PT. Panca Usaha Palopo Plywood. Tujuan penelitian ini adalah untuk mengetahui dan menganalisis tingkat efisiensi biaya pada PT. Panca Usaha Palopo Plywood 


\section{Metode Penelitian}

Tempat dan Waktu Penelitian

Penelitian ini dilakukan di PT. Panply Desa Baroa, Kecamatan Bua, Kabupaten Luwu dengan waktu penelitian kurang lebih 2 (dua) bulan.

Jenis dan Sumber Data

1. Data Primer

2. Data Skunder

Populasi dan Sampel

Populasi yang ada dalam penelitian ini

Metode Pengumpulan Data

Metode Pengumpulan data yang digunakan adalah: (a) Penelitian Pustaka (Library Research); Yaitu penelitian yang dilakukan dengan membaca buku dan literature yang ada kaitannya dengan objek yang diteliti, (b) Penelitian Lapangan (Field Research); Merupakan penelitian yang dilakukan secara langsung pada PT. Panply untuk mendapatkan data yang lengkap sesuai kebutuhan

Metode Analisis Data

Metode analisis data yang digunakan adalah metode analisis selisih (Varians) yang terdiri dari a) varians bahan baku, b) varians biaya tenaga kerja langsung, dan c) varians overhead pabrik, dengan menggunakan formulasi sebagai berikut.

a) Varians bahan baku

$$
\mathrm{SHB}=(\mathrm{HS} \times \mathrm{KS})-(\mathrm{HSt} \times \mathrm{KS})
$$

Di mana:

SHB = selisih harga bahan baku

HS = harga beli sesungguhnya setiap tahun

KS = Kualitas Sesungguhnya Yang Dibeli

HSt = harga beli standar setiap satuan

b) varians biaya tenaga kerja langsung

$$
\begin{aligned}
& \text { STU }=(\text { TS x JS })-(\text { HSt x JS }) \\
& \text { SHB }=\text { selisih Trif Upah Langsung } \\
& \text { TS }=\text { tarif sesungguhnya dari upah langsung perjam } \\
& \text { TSt }=\text { tariff standar dari upah langsung perjam } \\
& \text { JS } \quad=\text { jam sesungguhnya' }
\end{aligned}
$$


c) varians overhead pabrik,

ST = BOPS - AFKSt
ST = Selisih terkendalikan
BOPS = tarif Biaya overhead pabrik sesungguhnya
AFKSt = anggaran fleksibel pada kapasitas atau jam standar

\section{Hasil Penelitian Dan Pembahasan}

a) Hasil Varians bahan baku

$$
\begin{aligned}
(2008) \mathrm{SHB} & =(\mathrm{HS} \times \mathrm{KS})-(\mathrm{HSt} \text { X KS }) \\
& =(2.065 .000 \times 23.626 .476)-(2.103 .187 \times 23.626 .476) \\
& =48.788 .672 .940-49.690 .897 .179 \\
& =902.224 .237(\mathrm{~L}) \\
(2009) \mathrm{SHB} & =(\mathrm{HS} \times \mathrm{KS})-(\mathrm{HSt} \times \mathrm{KS}) \\
& =(3.563 .000 \times 39.767 .365)-(3.560 .787 \times 39.767 .365) \\
& =141.691 .121 .495-141.603 .116 .316 \\
& =88.005 .179(\mathrm{R}) \\
(2010) \mathrm{SHB} & =(\mathrm{HS} \times \mathrm{KS})-(\mathrm{HSt} \times \mathrm{KS}) \\
& =(3.203 .185 \times 34.474 .510)-(3.231 .986 \times 34.474 .510) \\
& =110.428 .233 .314-111.421 .676 \\
& =992.900 .362(\mathrm{~L})
\end{aligned}
$$

Hasil penelitian menyatakan bahwa selisih laba ini terjadi karena bagian pembelian telah membeli bahan baku dengan harga yang lebih rendah dari harga standar. Sedangkan hasil penelitian kuantitas sesungguhnya yang dipakai sama dengan kuantitas standar yang dipakai sama dengan kuantitas standarb yang dipakai sehingga tidak terdapat selisih baik laba maupun rugi.

b) Hasil Varians Tenaka kerja langsung

Berdasarkan perhitungan selisih tarif upah bahwa tidak terjadinya selisih laba maupun rugi karena perusahaan membayar tarif setandar upah. Setelah dilakukan penelitian data tahun 2008, 2009, 2010 mendapatkan hasiul bahwa tarif sesungguhnya sama dengan tarif standar sehingga tidak terdapat selisih baik laba maupun rugi. Sedangkan dalam penelitian berdasarkan selisih efisiensi upah langsung yaitu jam sesunggunya yang yang digunakan sama dengan jam standar yang ditetapkan. Kemudian menurut hasil penelitian data tahun 2008, 2009, 2010 bahwa jam sesungguhnya sama dengan jam standar sehingga tidak terdapat selisih laba maupun rugi dalam efisiensi upah langsung. 
c) Hasil varians overhead pabrik

Dalam penelitiannya data tahun 2008, 2009, 2010 didapat bahwa terjadi selisih laba yang bersifat menguntungkan karena kapasitas normal lebih kecil dari pada kapasitas standar.

Pembahasan Hasil Penelitian

Bersadarkan hasil analisis selisih maka dapat diketahui tingkat efisiensi biaya yang digunakan dalam proses produksi yang hasilnya menunjukkan tidak ada perbedaan yang signifikan antara selisih (varians) biaya produksi plywood tahun 2008, 2009, 2010 Berdasarkan perhitungan selisih harga bahan baku didapat bahwa pada tahun 2008 dan 2009 terdapat selisih laba sedangkan tahun 2009 terdapat selisih rugi, berdasarkan kuantitas bahan baku tahun 2008, 2009, 2010 tidak terdapat selisih laba maupun rugi, berdasarkan selisih tarif dan selisih efisiensi upah langsung tidak terjadi selisih dan berdasarkan selisih terkendali dan selisih volume maka terjadi selisih laba yang bersifat menguntungkan.

\section{Penutup}

Kesimpulan penelitian ini adalah bahwa faktor yang dapat meningkatkan efisiensi biaya adalah adanya akuntansi pertanggungjawaban dalam mengawasi kinerja manajer termasuk penetapan biaya standar dan informasi realisasi biaya serta adanya struktur organisasi. Berdasarkan analisis selisih (varians) dapat diketahui tingkat efisiensi total biaya produksi serta perbedaan yang terjadi tidak signifikan antara selisih biaya produksi. Adapun saran dari penelitian ini adalah: (a) Penetapan standar untuk biaya bahan baku, biaya tenaga kerja langsung dan biaya overhead pabrik hendaknya lebih cermat dengan memperhatikan faktor-faktor baik dalam perusahaan maupun dari luar perusahaan agar selisih (varians) yang terjadi dapat diminimalisir, (b) Pemisahan biaya yang digunakan untuk produksi plywood khususnya untuk biaya overhead pabrik, pencatatan dan pemisahan biayanya harus lebih teliti dan akurat menyangkut biaya tetap dan biaya variabel, (c) Terjadinya selisih yang menguntungkan merupakan keberhasilan pihak perusahaan yang mesti dipertahankan dengan memperhatikan biaya yang direncanakan dengan yang sesungguhnya digunakan agar tahun berikutnya efisiensi biaya dapat lebih ditingkatkan. 


\section{Daftar Pustaka}

Buystami Bastian, dan Nurlela, (2009), Akuntansi Biaya, Melalui Pendekatan Manajerial, Edisi Pertama, MitraWacana Media, Jakarta

Dewi blog's (2009), Perbedaan Efisiensi dan Efektifitas, Simkes MIKM Undip semarang.

Mariska, (2010), Peranan Sistem Akuntansi Pertanggung Jawaban dalam Pengukuran Kinerja \& Pengendalian Biaya Pusat, Universitas Widyatama

Mulyadi, (2001), Akuntansi Manajemen Konsep Manfaat Rekayasa, Cetakan Kesatu, Edisi Ketiga, BPFE dan STIE YKPN, Yogyakarta

Mursyidi, (2008), Akuntansi Biaya , Cetakan Pertama, Penerbit: Refika Aditama, Bandung.

Only Blues, (2009) Analisis Informasi Akuntansi Diferensial Sebagai Bahan Pertimbangan Manajemen untuk Menerima atau Menolak Pesanan pada PT. Winner Food, Jakarta.

Pinasih, (2005), Pengaruh Efisiensi Biaya Bahan Baku dan Efisiensi Tenaga Kerja Langsung Terhadap Profit Margin, Universitas Negeri Semarang

Prawirenegoro, Darsono, dan Ari Purwanti, (2009), Akuntansi Manajemen, Edisi Ketiga, Mitra Wacana Media, Jakarta

Pulung Vitasari, (2007), Penerapan Akuntansi Varians Sebagai Kontrol Efisiensi Biaya Produksi, Universitas Negeri Semarang

Samryn, LM., (2005), Akuntansi Manajemen Suatu Pengantar, Edisi Ketiga, Cetakan Kedua, Raja Grafindo Persada, Jakarta

Suryabrata, Sumadi, (2007), Metodologi Penelitian, CV. Rajawali Jakarta

Syahrul Rambe, (2007), Akuntansi Pertanggungjawaban Sebagai Alat Penilai Kinerja Manajer, Fakultas Ekonomi Universitas Sumatera Utara.

Witjaknarko, (2006), AkuntansiBiaya, Edisi Pertama, Cetakan Pertama, Penerbit: Graha Ilmu, Yogyakarta 